Abstracta Iranica Abstracta Iranica

Revue bibliographique pour le domaine irano-aryen

Volume 22 | 2001

Comptes rendus des publications de 1999

\title{
A Short History of the Ismailis. Traditions of a Muslim Community. Edinburgh, Edinburgh University Press, 1998, 248 p., Index.
}

\section{Christian Jambet}

\section{(2) OpenEdition}

1 Journals

\section{Édition électronique}

URL : http://journals.openedition.org/abstractairanica/36740

DOI : 10.4000/abstractairanica.36740

ISSN : 1961-960X

Éditeur :

CNRS (UMR 7528 Mondes iraniens et indiens), Éditions de l'IFRI

\section{Édition imprimée}

Date de publication : 15 mai 2001

ISSN : 0240-8910

\section{Référence électronique}

Christian Jambet, «A Short History of the Ismailis. Traditions of a Muslim Community. Edinburgh, Edinburgh University Press, 1998, 248 p., Index. », Abstracta Iranica [En ligne], Volume 22 | 2001, document 326, mis en ligne le 17 février 2010, consulté le 13 octobre 2020. URL : http:// journals.openedition.org/abstractairanica/36740; DOI : https://doi.org/10.4000/abstractairanica 36740

Ce document a été généré automatiquement le 13 octobre 2020

Tous droits réservés 


\title{
A Short History of the Ismailis. Traditions of a Muslim Community. Edinburgh, Edinburgh University Press, 1998, 248 p., Index.
}

\author{
Christian Jambet
}

L'A. fait mieux qu'une reprise abrégée de son monumental ouvrage, The Ismấilis: their History and Doctrines (Cambridge, 1990). Il embrasse l'ensemble de l'histoire de l'ismaélisme, selon une périodisation devenue classique. Nous retiendrons spécialement les pages éclairantes consacrées à l'expérience d'Alamūt et les longs développements sur l'ismaélisme post-alamūtĩ dans le sous-continent indien (ce pour quoi on se reportera aux importantes remarques de Tazim R. Kassam, Songs of Wisdom and Circles of Dance, Albany, 1995). Les œuvres philosophiques, morales ou mystiques principales sont brièvement mais exactement analysées en fonction des connaissances les plus récentes. L'A. soutient la thèse qui veut que l'ismaélisme nizārī soit l'aboutissement logique de l'ensemble de la gnose ismaélienne, sans toutefois ignorer l'héritage țayyibì. Au total, un ouvrage inspiré et une référence désormais nécessaire.

INDEX

Thèmes : 7. Islam 
AUTEURS

CHRISTIAN JAMBET

Paris 